\title{
The reception of Cicero's speeches in the early empire
}

\section{Introduction}

The reception of Cicero in the early empire has been fortunate in its interpreters. The picture as a whole has been the object of some recent surveys. ${ }^{1}$ And two important monographs have explored in detail the transformation of Cicero into a cultural and educational resource for the Roman elite during this period. ${ }^{2}$ From their distinctive perspectives, each has shown how pedagogical engagements with Cicero were shaped both by the desire to understand and learn effective oratorical techniques and by Cicero's position as a notable, albeit complex, cultural icon.

The object of this paper is to explore the early reception of Cicero beyond the twin poles of education and exemplarity on which both Keeline and La Bua have focused. I suggest that not all engagement with Cicero's texts were instrumental: there is also evidence that some readers, at least, approached Cicero as an author to be read and even enjoyed for reasons that were not to be entirely explained by their desire to become better or more effective speakers. Evidence for this kind of reading can be found in a number of writers from the first century A.D. who engage with a range of rhetorical approaches and topics and who employ the tropes of didacticism to frame their works without being pedagogical writers in any straightforward sense. Through a survey of the role of Cicero within the texts of the Elder Seneca, Asconius, and Quintilian, it is possible to demonstrate how "Cicero" remained a complex and multi-faceted figure throughout the first century A.D., not reducible to a single message or interpretation.

\section{The Elder Seneca}

The Elder Seneca's collections of declamatory practice, the Suasoriae and the Controversiae, provide some of the most important evidence for the reputation of Cicero in the very early empire: though written towards the end of Seneca's

1 Kennedy 2002; Gowing 2013.

2 Keeline 2018; La Bua 2019.

๑ OpenAccess. () 2022 Catherine E.W. Steel, published by De Gruyter. (cc) BY This work is licensed under the Creative Commons Attribution 4.0 International License. https://doi.org/10.1515/9783110748703-014 
life, they record material and ideas which he had encountered in the first years of Augustus' reign. They indicated that the reception of Cicero had already, within no more than two decades of his death, developed distinct manifestations in which his skill as a speaker and the details of his biography could feature as separate elements.

In Seneca's recollections, the figure of Cicero plays two distinct though complementary roles. On the one hand, Cicero provides a model of eloquence and, in some sense, a forebear of declamatory practice. His lifetime provides the chronological marker for when oratory flourished most at Rome: "whatever Roman eloquence has to match or surpass arrogant Greek flourished in Cicero's time: all the intellects who have shone in our studies were born then". ${ }^{3}$ In one controversia, Cicero is cited as the author of a sententia "which he delivered in a similar controversia". ${ }^{4}$ This sententia was one which all the declaimers on this topic, according to Seneca, adapted for use in their own contributions. In addition the acknowledgement of Cicero's status as a speaker, his life and actions had become a topic for declamatory activity. The events towards the end of his life, in particular, shape his death into an exemplar of self-determination in the face of tyranny by means of voluntary death. ${ }^{5}$ The fact that each of incidents which forms the basis for these treatments is fictional serves merely to show the potency of Cicero as a thought-experiment for testing out the limits of duty and political accommodation required in periods of civil conflict. In the course of recording material to illustrate these exercises, Seneca not only records the declamatory contributions of his peers and seniors but also creates, in Suasoria 6, an archive of Cicero's death, quoting at length from works by Pollio, Livy, Aufidius Bassus, Cremutius Cordus and Bruttedius Niger before concluding with a 25-line quotation of hexameters by Cornelius Severus from a historical verse epic composed in the Augustan period. The loss of all of this material in any other format makes this collection of inestimable value in assessing the cultural value and points of contestation around the memory of Cicero. ${ }^{6}$

3 Sen. contr. 1.6: Quidquid Romana facundia habet quod insolenti Graeciae aut opponat aut praeferat circa Ciceronem effloruit; omnia ingenia quae lucem studiis nostris attulerunt tunc nata sunt. Translations are my own.

4 Sen. contr. 1.4.7.

5 The relevant material is contr. 7.2, concerning the case of Popillius, Cicero's assassin, who had previously been defended by him; see suas. 6, in which Cicero considers whether to beg Antony for mercy; and suas. 7, in which Cicero considers whether to burn his writings since Antony promises to spare his life if he does so.

6 Roller 1997; Richlin 1999. On Cicero's death see also Keeline (p. 119-142) in this volume. 
However, if the Elder Seneca's Controversiae and Suasoriae were all that survived of classical literature, we would have from them very little detail about Cicero's own works to explain why they - and he - were apparently so important in the memories and oratorical techniques of the succeeding generation. A survey of all the references to Cicero's speeches shows how limited is the engagement of Seneca and those whose discussions he records with the details of Cicero's record as a practising orator.

In Suasoria 6, some of the suggested approaches to the question of whether Cicero should ask Antonius for pardon involve discussion of particular episodes during his career: in most cases, this is done in order to present a view of Cicero which is incompatible with his deciding now to appeal to Antonius. These are episodes at which Cicero's contributions was as a speaker, and so their representation in this context involves quotation or reminiscence from the speeches. ${ }^{7}$ Quintus Haterius alludes to Cicero's presentation of Milo's unwillingness to appeal to the jurors' pity at Milo's trial to construct an exhortation to Cicero against appealing to Antonius' pity: "You say, 'Milo forbids me to appeal to the jurors': go now and appeal to Antonius". ${ }^{8}$ Haterius' words refer to the very end of the pro Milone and the words "But let there be an end: I cannot now speak for tears, and this man forbids his defence through tears". ${ }^{9}$ The allusion would be clear to any reader who knew Cicero's text, but the only linguistic overlap is the single word vetat, and Haterius also omits the tears which are so prominent in Cicero's tactics. There is a direct quotation in Porcius Latro's version: he repurposes the Catilinarians "o tempora, o mores" as the unavoidable response to the triumviral proscriptions, drawing attention as he does so to their Ciceronian origin. ${ }^{10}$ Latro also describes, among the horrors that Cicero will see if he does live, is "that place in front of the tribunal which recently the master of horse, in whom it would be disgraceful even to belch, fouled with his vomit" ${ }^{11}$ This is a rewriting of Cicero's description of Antony's gastric misadventure from the sec-

7 On the shift from Cicero as orator across a range of genre within the context of Republican politics, to Cicero as a symbol of eloquence, see Kaster 1988.

8 Sen. suas. 6.2: Vetat, inquis, <me> Milo rogare iudices: i nunc et roga Antonium (me suppl. Studemund).

9 Cic. Mil. 105: Sed finis sit: neque enim prae lacrimis iam loqui possum, et hic se lacrimis defendi vetat.

10 Sen. suas. 6.3: Tuis verbis, Cicero, utendum est: "O tempora, o mores".

11 Sen. suas. 6.3: Videbis illum pro tribunali locum quem modo magister equitum, cui ructare turpe erat, vomitu foedaverat. 
ond Philippic. ${ }^{12}$ It includes a six word quotation (allowing for a shift in the mood of esse) though it is also evident that Latro has toned down the graphicness of the visual image that Cicero created with its description of Antonius' vomit and where it landed. He has also eliminated the constitutional impropriety which Cicero brings out by observation that Antonius was at the time of the incident "carrying out public business". Varius Geminus also referred to the Catilinarians and the Philippics in his declamation in support of the opposite view: he quoted Cicero's statement in the opening of the fourth Catilinarian - part of which Cicero himself quoted in the second Philippic - that death cannot be "early for a consular or miserable for a wise man" only to reject it in the new context in which Cicero found himself. ${ }^{13}$ Cicero's self-quotation underscores the probability that this phrase had become a well-known Ciceronian tag.

The conspiracy of Catiline, the defence of Milo and the Philippics were all iconic moments in Cicero's career and in its reception, a point to which I return below. One other speech is referred to in Suasoria 6, the lost Pro Vatinio, also by Varius Geminus in his approach to the opposite side of the question. He offers it as an example from Cicero's own earlier career of a willingness to be won over by an enemy, which therefore offers an example of reconciliation which Cicero could draw upon in being reconciled to Antonius. ${ }^{14}$ Elsewhere in the Controversiae and Suasoriae there only two direct references to Cicero's speeches. One is to the pro Milone, in the context of Seneca's reminiscences of Cassius Severus in the preface to book 3 of the Controversiae; Severus recalled a visit to Cestius' school when Cestius was about to offer his own In Milonem. ${ }^{15}$ The other occurs in a discussion of a controversia relating to familial relations during the Civil War, which hypothesises a woman forced by her father to kill herself for supporting her husband's adherence to the opposite side. Seneca records how Albucius Silus offered, as refutation of the equation of support for the opposing side with parricide, the example of Cicero's defence before Caesar of Ligarius. His summary

12 Cic. Phil. 2.63: In coetu vero populi Romani negotium publicum gerens, magister equitum, cui ructare turpe esset, is vomens frustis esculentis vinum redolentibus gremium suum et totum tribunal implevit.

13 Cic. Cat. 4.3: nam neque turpis mors forti viro potest accidere neque immatura consulari nec misera sapienti; cf. Phil. 2.119. Sen. suas. 6.12: Quod grandia loquitur et dicit: "Mors nec immatura consulari nec misera sapienti," non movet me.

14 Sen. suas. 6.13. On the pro Vatinio, Crawford 1994, 7-18.

15 On the composition of "fictional" speeches in declamation, see Peirano 2012, 12-27. 
contains a brief reference to one of Cicero's tactics in that speech, namely the acknowledgement that Ligarius is guilty of the charge of being in Africa. ${ }^{16}$

Seneca's self-imposed task is to record the declaimers who were his contemporaries. In the context of that piece of triumviral and Augustan literary history, Cicero is already present in a variety of ways. But it seems that from a declamatory perspective, Cicero's biography is most interesting; his life and more particularly death provide suitable topics for treatment. He is also in some sense a forebear of recent and contemporary declamatory practice. But he is not a stylistic influence, and with the exception of the Catilinarians and the Second Philippic he is not a quotable source, either. It is the contextual aspect of Cicero qua orator which provides the useful material, at least as much as his actual words. What, however, is more difficult to determine is whether this set of material shows a distinct bias towards specific speeches. The numbers are small, and only one - pro Milone - is referenced more than once.

\section{Asconius Pedianus}

A generation or so later, Cicero's oratory was for Asconius an object worthy of the most detailed and careful scrutiny, reflected in the preparation and dissemination of detailed notes and explanatory material on individual speeches. ${ }^{17}$ But Asconius' surviving text is interested in a rather restricted range of questions. The focus is on contextual, political, religious and prosopographical information; it does not seek to elucidate rhetorical questions. It also seems that Asconius was interested in the whole range of Cicero's speeches: the five commentaries which survive deal with both deliberative and forensic material. He handles two speeches delivered in the senate and three in the courts, and each of the latter was delivered in front of a different quaestio. Moreover, only one of these five, that is the pro Milone, seems to have had a significant presence in the educational curriculum, and there is no representation of the three collections of speeches, the Verrines, Catilinarians, and Philippics, which dominated pedagogical approaches to Cicero. Given that it is quite possible that what survives of Asconius was only part of what he wrote in this format, it is difficult to draw any firm conclusions about the nature of his project overall in terms of its aspirations to comprehensiveness and the aims underpinning his choice of speeches, if it was not,

16 Sen. contr. 10.3.3: Si parricidium esset fuisse in diversis partibus, numquam defendisset apud Caesarem Ligarium Cicero. M. Tulli, quam leve iudicasti crimen de quo confessus es! 17 On Asconius' commentary format, see Lewis 2006, XIV-XVI; La Bua 2019, 77-78. 
that is, conceived as a complete edition. But even from the limited sample that we have, Asconius' Cicero looks rather different from the Cicero found in schools.

An analysis of how Asconius constructs each commentary reveals the aspects of the speeches in which he was most interested. Each begins with the argumentum, that is the background to the charge or debate about which the speech was delivered, and the chronology leading up to its delivery. This precedes the enarratio with its detailed notes on a selection of lemmata from Cicero's text. Within this format, there is considerable variation in the relative lengths of the two sections: in the two senatorial speeches, the argumentum is around one-tenth of the length of the notes, whereas in the forensic speeches the argumentum varies from between slightly longer than one-quarter the length of the notes to approaching the same length. ${ }^{18}$ This disparity reflects the greater level of detail required to set the scene for forensic cases: in addition to the background to the alleged offence in the defendant's career, there is also information to include about the conduct of the trial and, in the case of Scaurus's defence, the identities of the different advocates involved in the trial. The very long argumentum in the pro Milone commentary is linked to the amount of historiographical material that Asconius could access on the death of Clodius and its violent aftermath. A focus on historical context is also evident in the notes. To take the commentary on pro Scauro, the shortest of the commentaries, as a brief example: there are thirteen individual notes. Of these, four add details about earlier forensic cases to which Cicero had referred in the speech. ${ }^{19}$ Five elucidate the details of an episode or individual. ${ }^{20}$ Two explain aspects of Rome's built environment to which the speech refers, and one adds information about the defendant's relatives, to whom Cicero had referred by relationship rather than name. ${ }^{21}$ So distinct, indeed, is Asconius' focus on people, events and things that the remaining note - a discussion of the conjunction ac neque (24C) - was deemed non-Asconian by Madvig (a decision which following editors have accepted) on the basis that its concentration on linguistic usage is entirely out of keeping with the work

18 The word-counts (based on Clark's text) are: Pis., 226: 2528; Sc., 539: 1575; Mil., 2499: 2640; Cor., 909: 3401; Tog. Can., 221: 2031.

19 Prosecutions of the elder Scaurus at a iudicium publicum and under the lex Servilia Caepionis (21C), under the lex Varia (22C); Scaurus' prosecution of Dolabella (25C).

20 The elder Scaurus' relationship with Cicero (22C); Tubulus as a potential defendant on poisoning charges (23C); the suicide of P. Crassus (23C and 25C); C. Claudius' electoral ambitions (25C).

21 Scaurus' house (26C-27C); the temple of Castor and Pollux (27C); Scaurus' maternal grandfather a Metellus (27C). 
as a whole (combined with an unfamiliarity with Ciceronian usage that seems improbable in Asconius). ${ }^{22}$

The lack of engagement with rhetoric in Asconius' text is more profound than simply an absence of comment on linguistic usage or figures or stylistic variation. There is little indication that Asconius wants his readers to approach these texts as rhetorical artefacts. So, for example, there is no analysis of individual passages in terms of the part of the speech to which they belong, or of their content as examples of a particular kind of speech, such as the point at issue in a forensic speech or the balance between advantageous and honourable within a deliberative speech. This is not of course to imply that Asconius' readers - or Asconius - were not competent or interested in rhetoric. It is not easy to conceive of contemporary readers of Asconius who had not had a thorough rhetorical education; and many will themselves have been practitioners. But the work shapes its readers as people who do not require rhetorical instruction. What they do need is information about the individuals, circumstances and political practices with which Cicero assumes his audience is familiar. By acquiring this knowledge, Asconius' readers can become Cicero's original audience. By undertaking the extensive research which underpins the commentaries and then shaping that into a series of notes on topics that might be obscure, Asconius has provided a shortcut which allows the reader of the mid-50s A.D. to share - at least in the case of a specific speech - the knowledge that Cicero's listeners and readers would have possessed in the 60s and 50s (or at least, that Cicero assumed they did). Asconius treats those who use his text as engaged and knowledgeable readers, not aspiring practitioners, and Cicero's speeches are objects of study as part of a shared cultural landscape rather than as tools to improve oratorical practice. He assumes his readers want to understand; but he does not seek to shape the ends to which that understanding might be put. ${ }^{23}$

\section{Quintilian}

The purpose of Quintilian's Institutio oratoria is a challenge, given the extent to which its scale and ambition mark it out from other surviving works of rhetorical instruction, and has been the object of recent discussion. ${ }^{24}$ It seems reasonable to see the work not as an instructional manual for teachers of rhetoric so much

22 I am grateful to John Ramsey for sharing with me and discussing his draft note on this passage from his forthcoming translation and commentary of Asconius.

23 On Asconius' historical research, see further Bishop 2015.

24 Roche 2016; Whitton 2019. 
as an advertisement to Rome's cultural elite of Quintilian's pre-eminence as a teacher. In this context, an analysis of Quintilian's engagement with Cicero a writer who underpins the whole of the work - supports the idea that Quintilian understood himself to be offering a contribution to a serious cultural debate about how to educate the next generation of the Roman elite. If we look closely at how Quintilian deploys Cicero's speeches in his work, we can see how he recruits his audience to his project by offering them a broad, challenging but ultimately accessible packaging of Cicero's speeches which flattered their sense of themselves as readers of Cicero. This results in an expansive understanding of Cicero which ranges far beyond a pedagogically-driven 'curriculum'.

One obvious and distinctive feature of Quintilian as a reader of Cicero is the range of speeches to which there is reference in the I.O. He refers to forty-eight of Cicero's speeches: this includes eleven speeches which do not survive in an independent manuscript tradition. ${ }^{25}$ There are eighteen surviving speeches to which Quintilian does not refer. ${ }^{26}$ There is no good reason to believe that Quintilian was not aware of the speeches which he does not cite; it is perhaps not surprising that Quintilian does not refer to every one of the large number of speeches available to him. ${ }^{27}$ This kind of explanation seems more convincing than one which sees a pattern of deliberate omission to shape a specific presentation of Cicero, though there are some interesting absences from such a perspective. ${ }^{28}$ Quintilian's Cicero is to a very great extent the speaker that Cicero himself wanted to preserve through the choices he made about the textual preservation of his oratory, and not the much more restricted Cicero of the educational curriculum.

However, this brief overview can be further developed. Quintilian's engagement with the speeches to which he refers is not uniform, and some are only mentioned once or twice. Eleven speeches receive more than ten references

25 In Clodium et Curionem; In competitores; Pro Cornelio; Pro Fundanio; In Gabinium; Pro Gabinio; Pro Gallio; Contra Metelli contionem; Pro Oppio; De proscriptorum liberis; Pro Vareno. The figure disaggregrates the different speeches within the Verrines, Catilinarians and Philippics collections. See also van der Blom (p. 247-266) in this volume.

26 Balb., dom., Marc., Planc., prov. cons., Q. Rosc., red. sen, red. pop., Sest., Sull and the $1^{\text {st }}, 5^{\text {th }}$, $5^{\text {th }}, 7^{\text {th }}, 10^{\text {th }}, 12^{\text {th }}, 13^{\text {th }}$ and $14^{\text {th }}$ Philippics.

27 For an unsystematic comparison with two modern works on Cicero which offer the impression of comprehensiveness without a format that systematically treats all Cicero's speeches, we can note that the Cambridge Companion to Cicero refers to forty-nine of Cicero's speeches and Gildenhard's Creative Eloquence to sixty-one.

28 So, for example, Quintilian does not cite either the De provinciis consularibus, with its abrupt shift in Cicero's attitude towards Caesar, or pro Marcello, with its strikingly innovative praise of Caesar. 
each. ${ }^{29}$ The pattern which this reveals, of a minority of speeches the focus of sustained and recurrent interest, and a much larger number referred to only sparingly, offers a better framework for understanding the complete absence of some speeches. The significant distinction is not between no mentions and one or two, but between a small kernel of Ciceronian texts to which Quintilian returns again and again and a much wider group of material which is only of occasional interest.

Is it possible to draw any conclusions about Quintilian's favourites? There is a distinct bias towards forensic speeches: the only deliberative speeches in this group are the first Catilinarian and the second Philippic, both capturing iconic moments in Cicero's career. ${ }^{30}$ Among the forensic speeches there is an intriguing mix - from the perspective of current research - of the familiar and the less familiar. ${ }^{31}$ The presence of Pro Vareno confirms that this speech is one of the more significant losses from the Ciceronian corpus, and Quintilian's interest in pro Cornelio echoes that of Asconius. A complete explanation for Quintilian's choices is not recoverable, but they are likely to have involved a combination of the didactic imperatives of the rhetorical classroom, and the inevitable centripetal momentum that attaches to any syllabus, with more unpredictable factors. We might well hypothesise that Quintilian used some speeches more than others in his teaching and so examples from those sprang more readily to mind for illustrative purposes; but we cannot disregard, though we cannot recover, the possibility that he had personal favourites, or the effects of recent exposure on the process of composition. We simply cannot know what Quintilian might have been reading as he put together the Instituio oratoria.

Analysis of references to individual speeches show the range of different functions that they fulfilled. If we take the Pro Caelio as an example, it can be seen that Quintilian's references divide in two general categories. Some refer to the speech as a whole or aspects of it but do not quote from the speech; others include quotations from the speech which are employed to illustrate a point. Among references in the former category, Quintilian comments in particular on the speech's proem, identifying a range of tactics that Cicero uses. These include its allusion to the time at which the trial is taking place (that is, on a holiday) (4.1.31); the way that Cicero attempts to trivialise the charges (4.1.59; 9.2.39);

29 They are: Caec. (14 references); Cael. (22); Cat. 1 (19); Cluent. (65); Corn. (13); Lig. (51); Mil. (64); Mur. (24); Phil. 2 (19); Var., (12); Verr 2.5, (34). See Table 1 in van der Blom (p. 264-266 in this volume).

30 The second Philippic was among the small group of speeches quoted in the Elder Seneca. 31 The Pro Ligario and Pro Caecina are perhaps particularly striking from this perspective. On Quintilian's interest in Lig., Johnson 2004. 
and his courteous approach to the prosecutor Atratinus (11.1.68). Quintilian also highlights particular aspects of the speech's organisation and tactics. He draws attention to the order in which its different arguments are put forward (4.2.27); Cicero's use against the prosecution of their own contradictory arguments (5.12.20), use of humour (6.3.25), and handling of the equestrian origins of the defendant (11.1.28). The prosopopoeia of Caecus at Cael. 33-35 is discussed twice, at different points in the work (3.8.54; 12.10.61). Quintilian's quotations from Pro Caelio involve questions of vocabulary (pusio, 8.3.22); figures (it is used to illustrate amplificatio, 8.4.1; interrogatio, 9.2.15; ethopoeia, 9.2.60; and the pursuit of elegance, 9.2.99); and rhythm (9.4.64, 97, 98, 102, 104). None of the quotations for vocabulary or rhythm identify the Pro Caelio as its source; as a result, the Institutio is a rather meagre source of fragments of Pro Caelio. ${ }^{32}$ The implication of this gap is not necessarily, though, that all readers were so familiar with the speech as not to need a reminder of the origin of a particular quotation. Instead, it might be that questions of prose rhythm and indeed of word choice could largely be handled in isolation from the broader issues in a speech and so it did not matter if all readers recognised the source of the quotation. However, when the example depended for its point on understanding the context of speech, as in the case of these figures, then the source is identified.

This distinction between familiarity with plot and case on the one hand and detailed linguistic analysis on the other points to the range of factors which influenced Quintilian's engagement with Cicero's texts. Quintilian was writing for an audience whose members were already very familiar with Cicero's works. Those for whom Quintilian's handbook was not of direct professional interest - that is, those readers who were not themselves engaged in teaching - could be expected to have a knowledge of Cicero's speeches shaped by their own educational experience and then developed, potentially, through reading Cicero as adults as well as reading the many other texts which, by the time that Quintilian was at work, dealt with Cicero systematically or engaged with his speeches and career in more selective ways. This pre-existing knowledge among different readers would have shared much of its fundamentals, given its basis in an education-

32 These are the quotations which can be identified as fragments of Pro Caelio on the basis of Quintilian alone: Cael. 32: Praesertim quam omnes amicam omnium potius quam cuiusquam inimicam putaverunt at 9.2.99; Cael. 35: Sed quid ego ita gravem personam introduxi? At 9.2.60; Cael. 38: Si vidua libere, proterva petulanter, dives effuse, libidinosa meretricio more viveret, adulterum ego putarem si qui hanc paulo liberius salutasset?, at 8.4.1; Cael. 39: Dicet aliquis: haec igitur est tua disciplina? Sic tu instituis adulescentis? [...] ego, si qui, iudices, hoc robore animi atque hac indole virtutis ac continentiae fuit, at 9.2.15. It is noticeable that they cluster in one limited (and particularly memorable) part of the speech. 
al process with a considerable degree of uniformity, whilst accommodating divergence in matters of detail and recall. Quintilian's text fits the prior experiences of Cicero that his readers brought to his text, but is not entirely dictated by it.

As a result, his Cicero combines the straightforwardly pedagogic with aspects that reach well beyond the classroom. His Cicero is indeed a source, through his speeches, to illustrate a range of rhetorical techniques. But Quintilian also lets his readers participate in a reading of Cicero that is both reassuringly familiar and at the same time flatteringly ambitious. It adopts the contours of the classroom and its set texts and it focusses on Cicero as an orator shaped for the needs of the legal and political elite, as a comparison with Pliny shows. ${ }^{33}$ But it also moves well beyond the purely instrumental. As readers, we recall with Quintilian the whole range of Cicero's speeches, we move fluidly between different speeches and, guided by deft reminders at key moments, we remember important contextual information when that is required in order to understand a specific example. Quintilian's is an inclusive Cicero: it generously supplements our existing recollections and shapes our understanding by its systematic and analytical approach to his corpus whilst sustaining the impression that he draws his material from a knowledge of Cicero's texts that is already shared with his readers.

\section{Conclusion}

This brief survey of Cicero's reception in the Elder Seneca, Asconius and Quintilian reveals a diversity of receptions. One aspect of this diversity is the range of different texts that each uses. As noted above, some care is needed in interpreting this range, particularly in the case of Asconius. Nonetheless, at the very least we can observe that the Ciceronian corpus has as yet undergone relatively little narrowing, at least for an educated adult audience. One specific indication of that breadth is the fact that only one speech features in all of these authors to any significant extent. This is Pro Milone: the case is alluded to twice by the Elder Seneca, is the object of by far the longest of Asconius' commentaries and is used more often by Quintilian than any other speech with the exception of Pro Cluentio (which exceeds it by a single reference). Its prominence within the Ciceronian corpus, and its shared importance within these three dif-

33 In the lengthiest discussion of Cicero's speeches in Pliny's Letters (1.20) he refers explicitly to Pro Vareno, Pro Murena, Pro Cornelio, Pro Cluentio and to the Verrines (the quotation he includes is from 2.4.5). The first four are among Quintilian's highly-cited speeches; the fourth Verrine just slips outside that group (Quintilian refers to it ten times). 
ferent approaches to Cicero, is not, I suggest, accidental, but is due to its distinctively complex status, which allowed it to be put to different uses. The continuing interest in Pro Milone underscores the extent to which the reception of Cicero in the first century A.D. resisted reduction to a single story.

The use of Pro Milone in education has been discussed at length by Keeline as a case-study in how students and their teachers approached a Ciceronian text. ${ }^{34}$ It stands out in the reception of Cicero precisely because of the amount of ancient evidence for how it was used. In addition to Asconius, and its importance to Quintilian, it is the object of attention by the Bobbio scholiast. None of these texts reveals explicitly why - or indeed whether - this speech had acquired a distinct place within the Ciceronian corpus but the fact that Cicero's speeches had initially at least avoided complete reduction to a narrow curriculum suggests that Pro Milone's popularity was not simply the result of tralatician return to a familiar text.

The origins of the events which led to Milo's trial involved political scandal and crisis at the highest level: a candidate for the consulship had murdered a candidate for the praetorship, and in the aftermath the senate house had burned down. To a greater extent than any other forensic case at which Cicero spoke even the Verrines or Pro Cornelio - the trial of Milo was an eye-catching public event, and one, moreover, which involved Cicero's defence of the man accused of murdering his own great enemy Clodius. Between the offence and the trial was over three months of tumultuous public debate at which the events on the Appian way had been revisited at contiones and in the senate, fresh and startling revelations had occurred, and fundamental principles of the organization of the res publica had been abandoned in a frantic attempt to restore order. When Cicero defended Milo, he did so in a court set up under very recent legislation sponsored by the sole consul Pompeius and in sight of an armed guard. The scale of the crisis is only dimly discernible in the surviving speech, for reasons intimately connected to that text's composition and aims; but it remained accessible to the inquiring reader, as Asconius demonstrates. Indeed, the Elder Seneca and his contemporaries would have been in a position to hear eye-witness accounts of the trial and the events which preceded it.

That background is probably to be seen as a factor in the enduring interest in Cicero's Pro Milone, but it may be more important at one remove. Cicero's defence of Milo was unsuccessful. This outcome was not a surprise, given his guilt, Pompeius' clear desire for a conviction, and the ongoing turbulence to the ending of which Milo's removal from the res publica might well seem to be a part. But it did

34 Keeline 2018, 13-72. 
reveal, as so much else in the 50s B.C. did, the limits to Cicero's influence and power. He decided to replay his defence, and attempt to overwrite his failure with a different speech. Since it is the revised Pro Milone which survives, it is an inherently provisional text. Milo could have been defended in a different way: because we know that he was, in fact, defended in a different way. Even in the other cases where Cicero circulated a text that he had not delivered, the illusion did not involve multiple versions; only in the case of Milo did the text evoke alternative possibilities. Brutus certainly responded to this provisionality by offering his own solution to the conundrum of how to defend Milo; and, as Seneca records, Cestius was moved to provide an In Milonem. ${ }^{35}$ It is possible, then, that the Pro Milone was so intriguing for subsequent audiences because it provided a unique opportunity to think through the choice of tactics in a forensic speech and to explore alternative routes to constructing a convincing defence to the ever-resonant charge of murder. The combination of the exemplary rhetorical brilliance on display in Pro Milone, its provisionality, and its position within the end of the Republic and Cicero's own career, served to support a variety of different readings of Cicero.

This diversity, a diversity of audiences as well as a diversity of approaches, is evident across the reception of Cicero in the three authors discussed in this chapter. It demonstrates that in the first century or so after Cicero's death, there were many different ways to be a reader of Cicero's speeches. These ways of reading were shaped but not fully determined by the initial educational encounters with Cicero which were shared by authors and readers. A single speech, most notably Pro Milone, could be read in a variety of ways; but even more importantly, the corpus of speeches did not, in this first century of reading Cicero, definitively shrink to a small core of set texts. The textual Cicero remained one that reflected a long and varied public career. We remain the beneficiaries of this early pluralism.

35 There is no evidence that Milo's actual prosecutors circulated their speeches. 
